\title{
Crystal structure of Ag-exchanged levyne intergrown with erionite: Single-crystal X-ray diffraction and Molecular Dynamics simulations
}

\author{
Georgia Cametti ${ }^{1, *+\uparrow}$ and Sergey V. Churakov ${ }^{1,2}$
}

\author{
${ }^{1}$ Institute of Geological Sciences, Mineralogical Crystallography, Baltzerstrasse 1+3, 3012 Bern, Switzerland \\ ${ }^{2}$ Paul Scherrer Institut, Forschungstrasse 111, 5232 Villingen PSI, Switzerland
}

\begin{abstract}
The modification of natural zeolites via ion exchange is an efficient technique used to improve their performances and tune their properties for specific applications. In this study, a natural levyne$\mathrm{Ca}$ intergrown with erionite was fully exchanged by $\mathrm{Ag}^{+}$and its structure [with idealized chemical composition $\mathrm{Ag}_{6}(\mathrm{Si}, \mathrm{Al})_{18} \mathrm{O}_{36} \cdot 18 \mathrm{H}_{2} \mathrm{O}$ ] was investigated by combining a theoretical and experimental approach. Single-crystal X-ray diffraction data demonstrated that Ag-levyne maintained the $R \overline{3} m$ space group, characteristic of the natural levyne. Ag ions distribute over partially occupied sites along the threefold axis and, differently from the pristine material, at the wall of the 8-membered ring window of the lev cavity. The lack of $\sim 30 \%$ of Ag ions that could not be located by the structural refinement is ascribed to the strong disorder of the extraframework occupants. The structural results obtained by Molecular Dynamics simulations are in overall agreement with the experimental data and showed that, on average, $\mathrm{Ag}^{+}$is surrounded by $\sim 2 \mathrm{H}_{2} \mathrm{O}$ and 1 framework oxygen at distances between 2.43 and 2.6 $\AA$. Molecular Dynamics trajectories indicate that the occurrence of silver inside the D6R cage depends on the water content: silver occupancy of D6R cages is estimated to be 83,30 , and $0 \%$ when the structure contains $3,2.5$, and $2 \mathrm{H}_{2} \mathrm{O}$ per Ag ion, respectively.

The cation-exchange process, as demonstrated by scanning electron microscopy and energydispersive spectroscopy (SEM-EDS) spectrometry, affects the intergrown erionite as well. A structural characterization of the Ag-erionite phase (with dimension $<100 \mu \mathrm{m}$ ) was possible by means of a $\mathrm{CuK \alpha}$ micro-focus source: structure solution pointed to $P 6_{3} / m m c$ space group, indicating no change with respect to natural erionite. In agreement with previous studies, $\mathrm{K}$ ions in the cancrinite cage could not be exchanged, whereas $\mathrm{Ag}^{+}$is found in the eri cavity.
\end{abstract}

Keywords: Zeolites, Ag-levyne, LEV, Ag-erionite, X-ray diffraction, Molecular Dynamics; Microporous Materials: Crystal-Chemistry, Properties, and Utilizations

\section{INTRODUCTION}

The mineral series levyne, comprising levyne-Ca and levyne$\mathrm{Na}$, belongs to the zeolites group. The crystal structure of these minerals is described by a three-dimensional aluminosilicate tetrahedral framework in which charge compensating alkali and/or alkaline earth cations and $\mathrm{H}_{2} \mathrm{O}$ occupy the structural voids. Due to their microporous structure, zeolite minerals show interesting properties such as cation exchange, adsorption, reversible hydration/dehydration and the capacity of acting as molecular sieves (Bish and Ming 2001). For this reason, they are successfully applied for a broad range of applications, and, in particular, in environmental remediation processes (treatment of radioactive wastewater and remediation of contaminated sites) (Colella 1999; Babel and Kurniawan 2003; Borai et al. 2009; Misaelides 2011; Wang and Peng 2010). Compared to their synthetic counterpart, natural zeolites typically show greater thermal stability and better resistance to acid environments (Ackley et al. 2003). Rich opportunities for technological applications, abundance in nature, and low mining costs motivates research on structural and chemical

\footnotetext{
* E-mail: georgia.cametti@krist.unibe.ch. ORCID 0000-0002-3186-3074

$\uparrow$ Special collection papers can be found online at http://www.minsocam.org/MSA/ AmMin/special-collections.html.
}

properties of natural zeolites in various scientific disciplines.

LEV-type zeolites are of interest because, despite their small pore openings, they show large micropore volume $\left(0.3 \mathrm{~cm}^{3} / \mathrm{g}\right)$ (Yamamoto et al. 2010). Thus, several phases with LEV topology have also been synthesized (Flanigen et al. 1986; Lock et al. 1984; Zhu et al. 1997) and Ca-LEV was suggested as potential hydrogen-storage medium (Liang et al. 2012).

The naturally occurring levyne belongs to the so-called ABC-6 family of natural zeolites (Gottardi and Galli 1985). The LEV framework type of levyne is characterized by a sequence of single six-membered rings $(6 \mathrm{mR})$ and double six-membered rings (D6R) of tetrahedra stacked along the $c$ axis following the AABCCABBCAA sequence. This sequence originates columns along [001] of cavities $\left[4^{9} 6^{5} 8^{3}\right]$ (lev cavity), which alternates with double six-ring $\left[4^{6} 6^{2}\right]$ polyhedra. Two dimensionally interconnected channels confined by eight-membered rings run perpendicular to [001]. The crystal structure at room temperature is described in $R \overline{3} m$ space group (Merlino et al. 1975; Sacerdoti 1996). Natural crystals of levyne are often twinned by $180^{\circ}$ rotation along the $c$ axis simulating $P 6 / \mathrm{mmm}$ symmetry (Sacerdoti 1996). Moreover, intergrowths with erionite/offretite, two other zeolites pertaining to the $\mathrm{ABC}-6$ family, have been frequently reported in natural occurring levyne (Shimazu and Mizota 1972; 
Bennett and Grose 1978; Wise and Tschernich 1976; Passaglia et al. 1974).

The microporous properties of natural zeolites are controlled by the extraframework (EF) cations content. The modification of their crystal-structure via cation exchange has been proven to improve their performances over a wide range of applications (Kasture et al. 1998; Ackley et al. 2003; Kanazawa 2004; Zukal et al. 2010; Amooghin et al. 2016; Ma et al. 2018; Abreu et al. 2019). In particular, Ag-exchanged zeolites show increased sorption and photocatalytic capacity (Hutson et al. 2000; CoutinoGonzales et al. 2015) and antibacterial efficacy (Milenkovic et al. 2017; Ferreira et al. 2012). To predict the zeolites behavior in terms of stability and microporous properties two factors are particularly important: (1) the position of the EF cations in relation to the aluminosilicate framework, and (2) the modification of the framework itself as a consequence of the EF cations substitution.

In this study, we investigate the crystal structure of Ag-levyne produced by cation exchange of a natural levyne-Ca. To determine the EF cation arrangement in the zeolitic channels and to have a better insight into the local environment of silver atoms and global structural disorder, we combined an experimental and theoretical approach. The average structural parameters were determined by means of single-crystal X-ray diffraction and compared with that obtained by Molecular Dynamics simulations. Moreover, a detailed structural characterization of the erionite intergrowths was also undertaken.

\section{MATERIALS AND METHODS}

The sample used as starting material was a natural levyne with chemical composition $\mathrm{Ca}_{2.53} \mathrm{Na}_{0.72} \mathrm{~K}_{0.23}\left(\mathrm{Al}_{6.26} \mathrm{Si}_{11.8} \mathrm{O}_{36}\right) \cdot 17.58 \mathrm{H}_{2} \mathrm{O}$ from Beech Creek, Oregon, U.S.A. The crystals were selected from the same specimen (sample number A7827 of Natural History Museum of Bern) used by Cametti (2018).

The exchange experiments were performed following two steps: at first, levyne crystals with dimensions ranging from 0.08 and $0.3 \mathrm{~mm}$ were treated for four weeks with $1 \mathrm{M} \mathrm{NaCl}$ solution at $100(2)^{\circ} \mathrm{C}$ in a Teflon (polytetrafluoroethylene) autoclave. The solution was renewed every three days. Afterward, the Na-exchanged crystals were equilibrated with a $2 \mathrm{M} \mathrm{AgNO}_{3}$ solution $(\mathrm{pH}=5-6)$ at $100(2){ }^{\circ} \mathrm{C}$ for five weeks. For this second exchange-step, the crystals were also located in a Teflon autoclave and darkness conditions were maintained during the whole experiment. The $\mathrm{AgNO}_{3}$ solution was periodically renewed every three days. The crystals were subsequently removed from the autoclave, washed with deionized water and analyzed by energy-dispersive spectrometry (EDS) using a ZEISS EVO50 scanning electron microscope (SEM) to ensure the completeness of the exchange process. Operating conditions were $20 \mathrm{kV}$ accelerating voltage, $10 \mathrm{~mm}$ working distance, $30 \mathrm{~s}$ acquisition time. An attempt to analyze the same samples with electron microprobe was not successful due to the small crystal size. Final chemical composition was calculated on the basis of $36 \mathrm{O}$ after renormalization of the chemical analyses hypothesizing a water content of $18 \mathrm{wt} \%$.

\section{Single-crystal X-ray diffraction (SCXRD)}

Diffraction data were collected on a Bruker APEX II diffractometer equipped with a MoK $\alpha$ source $(\lambda=0.71073)$ and a CCD detector. A single crystal of Aglevyne with dimension $0.180 \times 0.150 \times 0.100 \mathrm{~mm}$ was glued on the tip of a glass fiber and mounted on a goniometer head.

The unit-cell determination indicated a rhombohedral Bravais-lattice. An inspection of the reciprocal lattice pointed out the presence of an additional set of reflections $(\sim 6-7 \%$ of the total ones) that could be indexed with the same rhombohedral unit cell rotated by $180^{\circ}$ with respect to the $c$-axis. The data were integrated and corrected for absorption by using the Apex 3v.2018.7-2 software package (Bruker 2019).

The structure was solved in space group $R \overline{3} \mathrm{~m}$ by direct methods using SHELXTL-2008 (Sheldrick 2008). Structural refinement was carried out by SHELXL-2014 (Sheldrick 2015) by using neutral atomic scattering factors. Starting coordinates and atomic labels of framework atoms were those reported in Sacerdoti (1996), whereas the EF cations and $\mathrm{H}_{2} \mathrm{O}$ molecules were located by difference Fourier maps. The obverse-reverse twinning [ $\overline{1} 000 \overline{1} 0001]$ was refined with fractional volume contribution of $0.058(4)$.

Erionite and offretite intergrowths have been frequently reported for levyne specimen from the same locality (Bennett and Grose 1978; Passaglia et al. 1998; Cametti 2018). SEM-BSD pictures of our sample showed the occurrence of another fibrous-mineral phase intergrown between levyne crystals (Fig. 1). To find out whether the intergrown mineral was erionite or offretite and to determine how this phase was affected by the exchange experiments, single fragments of secondary phase were extracted to perform subsequent structural analyses. Fragments of Ag-exchange levyne were at first carefully inspected under a binocular microscope and disintegrated into smaller pieces with dimensions $<100 \mu \mathrm{m}$. To find the erionite/offretite crystals, several fragments were preliminary checked by single-crystal X-ray diffraction, to extrapolate the unit-cell parameters. Finally, a crystal with dimension of approximately $0.05 \times 0.03 \times 0.015 \mathrm{~mm}$ was identified as erionite.

A single crystal of erionite-Ag was glued on the tip of a glass fiber and mounted on a goniometer head. Diffraction data were collected on a Synergy-S Rigaku dual micro-focused source diffractometer equipped with a Hypix detector. The $\mathrm{CuK \alpha}$ $(\lambda=1.54184)$ radiation was chosen for data collection due to the small dimensions of the crystal under investigation. An attempt to measure the same sample with $\mathrm{Ag} K \alpha$, available on the same machine, or with $\mathrm{MoK} \alpha$ used for the Ag-levyne $\mathrm{X}$-ray data collection, was not successful because of the low diffracting power of such a small crystal fragment. Diffraction data were integrated and corrected for absorption by using CrysAlis Pro (2018). Erionite crystal structure was solved by direct methods in space group $\mathrm{Pb}_{3} / \mathrm{mmc}$.

Crystal data, collection, and refined parameters are reported in Supplemental ${ }^{1}$ Table S1. The crystallographic information file ${ }^{1}$ (CIF) of the refined structures has been deposited. The drawings of the crystal structures were produced by VESTA (Momma and Izumi 2011).

\section{Molecular Dynamics (MD) simulations}

Molecular Dynamics simulations were performed using the CP2 K simulation package CP2K (2000-2019). The equations of motion were integrated using a $0.5 \mathrm{fs}$ time step. The interatomic forces were calculated based on Density Functional Theory (DFT) using the Gaussian and plane waves methods (VandeVondele et al. 2005a). The electron exchange and correlations were described by PerdewBurke-Ernzerhof functional (PBE) (Perdew et al. 1996). Dispersion interaction was taken into account using the DFT+D2 method (Grimme et al. 2006). The calculations were carried out in NPT ensemble (constant pressure and temperature using a fully flexible cell). Indeed, although atomistic simulations with fixed cell parameters can provide a satisfactory atomistic description of the extraframework content (Gatta et al. 2018), NPT ensemble was chosen in this study to take into account the strong disorder of the EF content and improve the convergence toward the stable configuration.

The simulations temperature of MD was set to $77^{\circ} \mathrm{C}$ to prevent the glassy behavior of PBE- $\mathrm{H}_{2} \mathrm{O}$ (VandeVondele et al. 2005b). The use of slightly elevated temperature makes sure ergodic dynamic of ions and water in the channels. The experimental measurements suggest that the space group symmetry does not change with in the given temperature range. The Kohn-Sham orbitals were expanded using a linear combination of atom centered Gaussian-type orbital functions. A "shortrange" double-valence polarized basis set MOLOPT was used for each atomic kind (VandeVondele and Hutter 2007). Similar setup was successfully used in our previous simulations of zeolites (Cametti et al. 2019a, 2019b).

The simulation supercell $(2 \times 1 \times 1)$ contained 684 atoms $(36 \mathrm{Ag}, 36 \mathrm{Al}, 72 \mathrm{O}$, $\left.216 \mathrm{O}, 108 \mathrm{H}_{2} \mathrm{O}\right)$. The starting coordinates of the framework atoms were those of levyne-Ca (Cametti 2018). Silicon was randomly substituted by aluminum according to the bulk chemical composition following the Loewenstein's rule (Loewenstein 1954). The Ag atoms were initially placed along the threefold axis parallel to [001] in the middle of each $\left[4^{9} 6^{5} 8^{3}\right]$ cavity. The number of $\mathrm{H}_{2} \mathrm{O}$ was set according to the idealized chemical composition of levyne that is $3.0 \mathrm{H}_{2} \mathrm{O}$ per EF cation (Passaglia and Sheppard 2001). The structural data were collected from a $25 \mathrm{ps}$ long MD trajectory followed by at least 6 ps pre-equilibration. Moreover, two additional structural models with 2.5 and $2 \mathrm{H}_{2} \mathrm{O}$ per $\mathrm{Ag}$ atom, respectively, were tested.

\section{RESULTS}

The EDS-SEM analyses of the Ag-exchanged levyne showed that $\mathrm{Na}^{+}$was completely replaced by $\mathrm{Ag}^{+}$. The detected amount of potassium was related to the occurrence of erionite inter- 


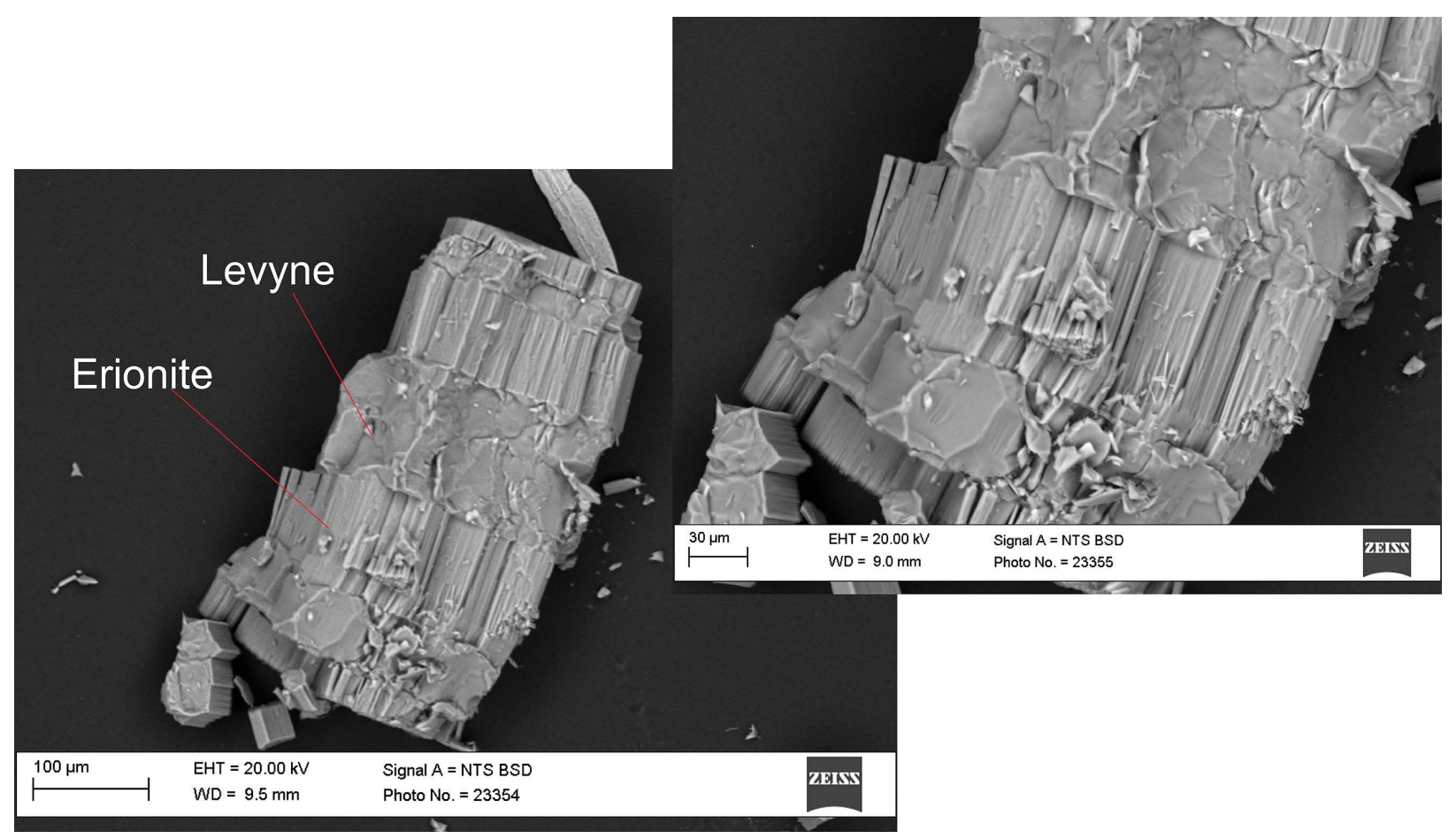

Figure 1. SEM BSD images of levyne-erionite intergrowths. (Color online.)

growths as confirmed by SEM pictures (Fig. 1). Within the same single crystal, two main domains can be recognized: one with a fibrous-like morphology, which mainly contains $\mathrm{K}$ and $\mathrm{Ag}$ as EF cations and, the other that is K-free. This kind of intergrowths, i.e., erionite on the $\{0001\}$ faces of levyne lamellae is frequent and was observed in samples from different localities (Passaglia et al. 1974; Bennet and Grose 1978; Wise and Tschernich 1976; Gottardi and Galli 1985). Final chemical composition for Ag-levyne and -erionite are $\mathrm{Ag}_{6.1} \mathrm{Al}_{6.3} \mathrm{Si}_{11.8} \mathrm{O}_{36} \cdot 18.0 \mathrm{H}_{2} \mathrm{O}$ and $\mathrm{Ag}_{8.9} \mathrm{~K}_{1.7} \mathrm{Al}_{10.1} \mathrm{Si}_{22.5} \mathrm{O}_{72} \cdot 30 \mathrm{H}_{2} \mathrm{O}$, respectively.

\section{Crystal structure of Ag-levyne}

The Ag-levyne structure at room temperature preserves the space group $R \overline{3} m$ characteristic of the natural levyne-Ca. The aluminosilicate framework did not show significant changes because of $\mathrm{Ag}^{+}$uptake. The unit-cell parameters were comparable with those of the pristine material (Cametti 2018). The dimension $(6.48 \times 7.39 \AA)$ of the apertures of the eight-membered ring channels along [100] was similar to that of levyne-Ca $(6.44 \times 7.42 \AA)$.

The structural refinement of the XRD data indicated that Ag ions are strongly disordered within the zeolitic pores. Four main EF Ag sites (Ag1, Ag2, Ag3, and Ag4) were located plus additional low-occupied sites (Ag1A, Ag2A, Ag2B, Ag4A, ... Ag4E) (occupancy $\sim 0.15$ ) close to the main ones (Fig. 2; Supplemental ${ }^{1}$ Table S2). The Ag1 site is the most populated, with occupancy $=0.429$ (19). In Ag-levyne, the Ag sites (Ag1, Ag2, and Ag3) are distributed along the threefold axis and, different to the EF cations in natural levyne-Ca, at the wall of the eight-membered ring window of the lev cage (Ag4) (Fig. 2). Ag ions at this position are extremely disordered and a simultaneous presence of $\mathrm{Ag}$ and $\mathrm{H}_{2} \mathrm{O}$ cannot be excluded.
In natural levyne-Ca (Cametti 2018), EF cations and $\mathrm{H}_{2} \mathrm{O}$ are found at five sites: (C1, C2, C3, C4, C5) and (W1, W2, W3, W4, W5), respectively. In Ag-levyne:

- Ag1 site corresponds to $\mathrm{C} 1$ that in levyne-Ca is almost fully occupied by $\mathrm{Ca}$;

- Ag3 site corresponds to $\mathrm{C} 2$, which in levyne-Ca is $13 \%$ occupied by $\mathrm{Ca}$;

- Ag2, Ag2A, and Ag2B correspond to C3, C4, and C5, respectively; these positions in natural levyne- $\mathrm{Ca}$, are partially occupied by $\mathrm{Na}, \mathrm{K}$, and $\mathrm{Ca}$, respectively (Cametti 2018).

- The positions of Ag4 sites (Ag4A, Ag4B, Ag4C, Ag4D, and $\mathrm{Ag} 4 \mathrm{E}$ ) are comparable to those of $\mathrm{H}_{2} \mathrm{O}$ at W2, W4, and W5 in levyne-Ca;

- W1 and W3 positions are identical in levyne-Ca and Aglevyne.

Relevant bond distances of Ag-levyne structure are reported in Table 1. Ag1 site is coordinated by three $\mathrm{H}_{2} \mathrm{O}$ at W1 [2.372(8) $\AA$ ] and three framework-oxygen atoms at O2 [2.470(5) $\AA]$, forming a fairly regular octahedron. $\mathrm{Ag} 2$ site bonds to six frameworkoxygen atoms at O5 [2.591(5) $\AA$, which constitute the aperture of the six-membered ring window of the lev cavity. Bond distances between 2.24 and $2.6 \AA$ are found for Ag4A, Ag4B, Ag4C, Ag4D, and $\mathrm{Ag} 4 \mathrm{E}$. On average, the sites at these positions bond to three oxygen atoms of the eight-membered ring aperture (two at $\mathrm{O} 1$ and one at $\mathrm{O} 3$ ) and two $\mathrm{H}_{2} \mathrm{O}$ at W3.

The total number of $\mathrm{Ag}$ ions per formula unit obtained by the structural refinement was lower compared to that estimated by the chemical analyses. On the basis of 36 oxygen, the total number of positive charges required to balance the negative charge of the aluminosilicate framework is 6. However, if all the EF sites are refined with the $\mathrm{Ag}$ scattering factor, the refined $\mathrm{Ag}^{+}$apfu 


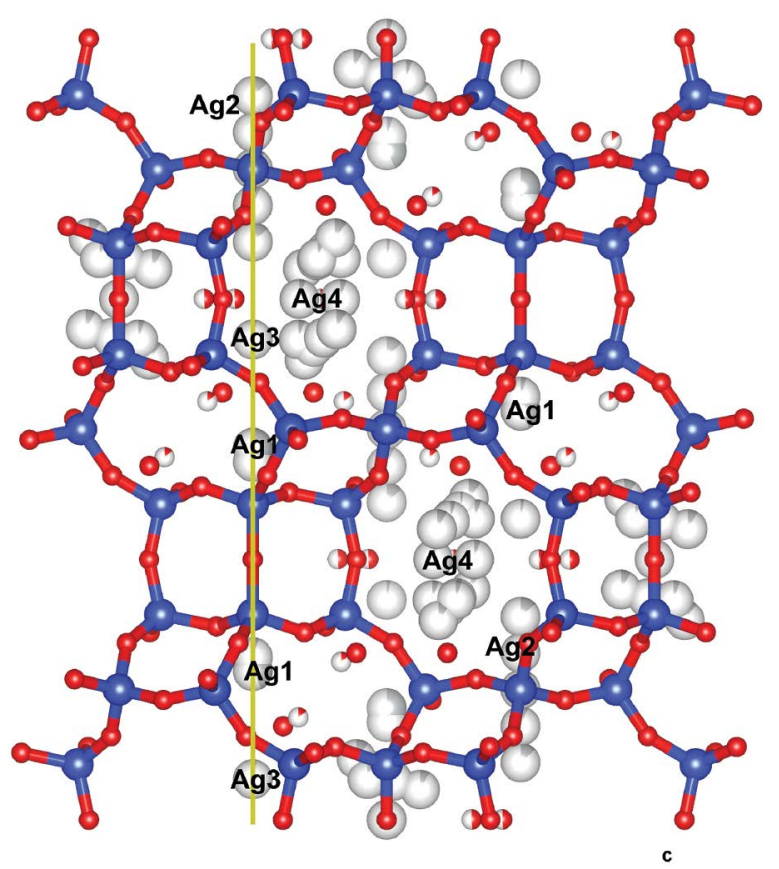

Figure 2. Crystal structure of Ag-levyne projected along [110]. Blue spheres represent the ( $\mathrm{Si}, \mathrm{Al})$ tetrahedral sites, silver and oxygen atoms are displayed in gray and red, respectively. Partially a colored spheres correspond to partial occupancy of the crystallographic sites. The yellow line indicates the threefold axis. (Color online.)

is only 4 , pointing out that $\sim 30 \%$ of the EF silver could not be located by XRD.

\section{Molecular Dynamics}

The unit lattice constants obtained by MD simulations are close to those obtained by XRD, with a deviation of $<1 \%$ for all parameters and $1.75 \%$ for the length of the c-axis (Table 2).

Figure 3 reports a snapshot of the structure obtained after $20 \mathrm{ps}$ calculation. Ag atoms are found mainly along the threefold axis and part of them are displaced toward the eight-membered ring window of the $l e v$ cavity. The radial distribution function (RDF) and running coordination number $(\mathrm{CN})$ of the Ag-O $(\mathrm{O}$ oxygen of the framework) and Ag-Ow (Ow oxygen of the $\mathrm{H}_{2} \mathrm{O}$ )

TABLE 1. Relevant bond distances ( $\AA$ ) of Ag-levyne structure at room temperature

\begin{tabular}{llll}
\hline \multicolumn{5}{c}{ Framework } \\
$\mathrm{T} 1-\mathrm{O} 4$ & $1.6431(14)$ & $\mathrm{T} 2-\mathrm{O} 5 \times 2$ & $1.6391(12)$ \\
$\mathrm{T} 1-\mathrm{O} 1$ & $1.645(3)$ & $\mathrm{T} 2-\mathrm{O} 1 \times 2$ & $1.647(3)$ \\
$\mathrm{T} 1-\mathrm{O} 3$ & $1.6558(16)$ & $<\mathrm{T} 2-\mathrm{O}>$ & 1.643 \\
$\mathrm{~T} 1-\mathrm{O} 2$ & $1.6800(19)$ & \\
$<\mathrm{T} 1-\mathrm{O}>$ & 1.656 & & \\
$\mathrm{Ag} 1-\mathrm{W} 1 \times 3$ & \multicolumn{4}{c}{ Extraframework } \\
$\mathrm{Ag} 1-\mathrm{O} 2 \times 3$ & $2.372(8)$ & $\mathrm{Ag} 4 \mathrm{~A}-\mathrm{O} 1 \times 2$ & $2.684(13)$ \\
\multicolumn{5}{c}{$\mathrm{Ag} 1 \mathrm{~A}-\mathrm{W} 3 \times 2$} & $2.77(3)$ \\
$\mathrm{Ag} 2-\mathrm{O} 5 \times 6$ & $2.470(5)$ & $\mathrm{Ag} 4 \mathrm{~A}-\mathrm{O} 5 \times 2$ & $2.765(11)$ \\
$\mathrm{Ag} 2 \mathrm{~A}-\mathrm{O} 5 \times 3$ & $2.591(5)$ & & \\
$\mathrm{Ag} 2 \mathrm{~B}-\mathrm{W} 3 \times 3$ & $2.682(7)$ & & \\
$\mathrm{Ag} 3-\mathrm{W} 1 \times 3$ & $2.60(3)$ & & \\
$\mathrm{Ag} 3-\mathrm{W} 3 \times 3$ & $2.33(2)$ & & \\
\hline
\end{tabular}

TABLE 2. Unit-cell parameters of Ag-levyne obtained from MD trajectories and SC-XRD data collected at RT

\begin{tabular}{lccc}
\hline & MD & XRD & Deviation \\
\hline$a$-axis $(\AA)$ & $13.47(8)$ & $13.4169(3)$ & $0.43 \%$ \\
$b$-axis $(\AA)$ & $13.52(8)$ & $13.4169(3)$ & $0.79 \%$ \\
$c$-axis $(\AA)$ & $22.98(14)$ & $22.5926(6)$ & $1.75 \%$ \\
$\mathrm{a}\left({ }^{\circ}\right)$ & 90.16 & 90 & $0.17 \%$ \\
$\mathrm{~b}\left({ }^{\circ}\right)$ & 89.90 & 90 & $0.11 \%$ \\
$\mathrm{Y}\left({ }^{\circ}\right)$ & 119.99 & 120 & $0.009 \%$ \\
Cell volume $\left(\AA^{3}\right)$ & $3621(13)$ & $3522.09(18)$ & $2 \%$ \\
\hline
\end{tabular}

Note: The deviation (in percentage) of MD unit-cell parameters from those obtained by SC-XRD is shown.

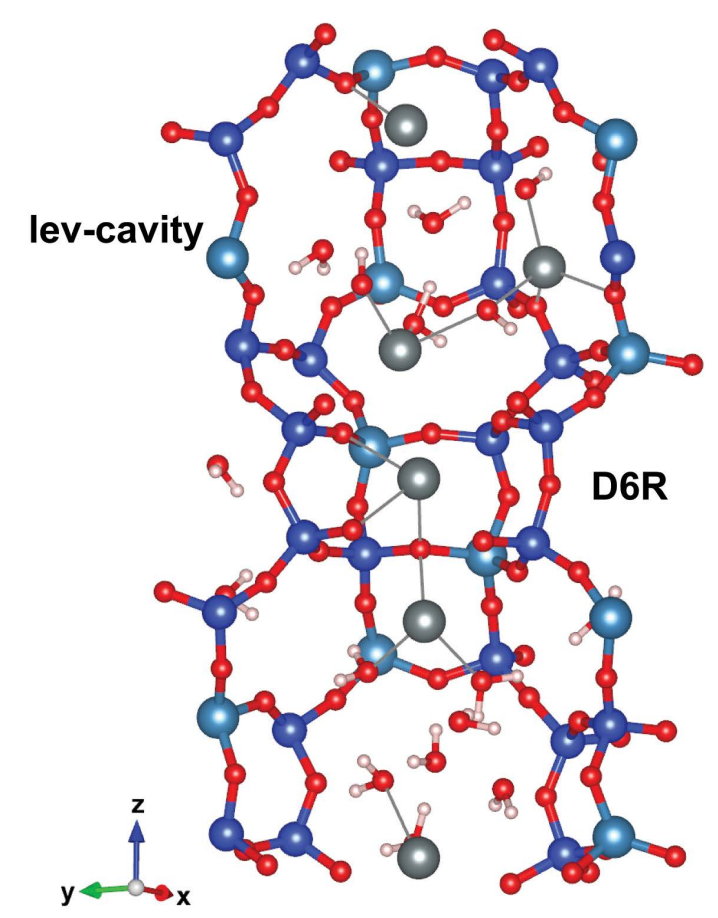

Figure 3. A snapshot of Ag-levyne structure after 18 ps MD simulation. Color code as in Figure 2. Al-occupied tetrahedral sites are shown as dark cyan spheres. Ag-O bonds are shown with gray lines. (Color online.)

are reported in Figure 4. The RDF of the Ag-Ow distances shows a clear peak at $2.43 \AA$, whereas the curve corresponding to Ag-O indicates a broadened distribution of distances with a maximum at ca. $2.5 \AA$. On average, each $\mathrm{Ag}$ is surrounded by $\sim 2 \mathrm{H}_{2} \mathrm{O}$ and 1 framework oxygen at distances between 2.43 and $2.60 \AA$.

The Ag ions in the lev cavity are found at the top and bottom of the cavity, close to the aperture of the six-membered rings (Fig. 5a). These atoms are coordinated by three-framework $\mathrm{O}$ atoms and by three $\mathrm{H}_{2} \mathrm{O}$, which occupy the central part of the cage. Additional Ag ions, located at the eight-membred ring windows, bond to two framework oxygen atoms and to two or three $\mathrm{H}_{2} \mathrm{O}$ (Fig. 5a). Such Ag distribution in the lev cavity agrees with that observed by the structural refinement (Fig. 5b) where $\mathrm{Ag}$ ions disordered at Ag4 sites are located on the wall of the aperture of the eight-membered ring. Additional disordered $\mathrm{Ag}$ atoms at $\mathrm{Ag} 2$ sites are distributed at the bottom of the cage.

In the simulation's setup with $3 \mathrm{H}_{2} \mathrm{O}$ per $\mathrm{Ag}$ atom, an additional $\mathrm{Ag}$ ion is found at $(0,0,0)$, in the middle of $\sim 83 \%$ of 


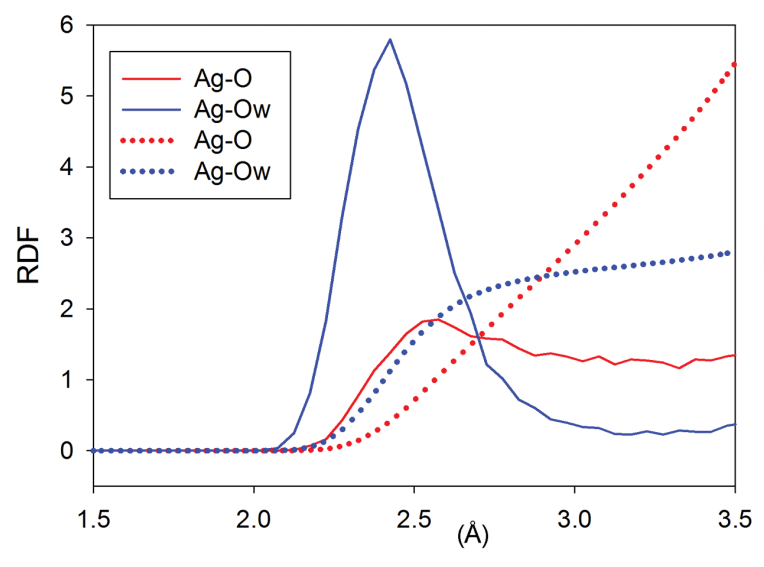

Figure 4. Radial distribution function (RDF) (continuous line) and coordination number $(\mathrm{CN})$ (dotted lines) of $\mathrm{Ag}-\mathrm{O}$ and $\mathrm{Ag}-\mathrm{O}$ w distances of Ag-levyne calculated from MD trajectories. (Color online.)

the double six-membered rings (D6R) cage (Fig. 3). In contrast, in the structural refinement, no residual electron density was found at this position and an attempt to insert an additional site at $(0,0,0)$ was not successful.

The hydrogen bond net of the structure with $3 \mathrm{H}_{2} \mathrm{O}$ mainly involves oxygen of the water molecules, whereas no significant interactions between $\mathrm{H}$ and framework $\mathrm{O}$ atoms were observed (each $\mathrm{O}$ has approximately only $0.2 \mathrm{H}$ atoms within $2.0 \AA$, Supplemental Material ${ }^{1}$ Fig. S1). The RDF and $\mathrm{CN}$ of $\mathrm{Ow}{ }^{\cdots} \mathrm{H}$ contacts show that, on average, $0.5 \mathrm{H}$ are found at a distance of $1.70 \AA$ from Ow, indicating a medium-strong character of such interactions (Supplemental Material ${ }^{1}$ Fig. S1). As expected, the number of the $\mathrm{Ow}^{\cdots} \cdot \mathrm{H}$ contacts decreases and becomes less significant if the modeled structures with 2 and $2.5 \mathrm{H}_{2} \mathrm{O}$ per $\mathrm{Ag}$ ion are considered (Supplemental Material ${ }^{1}$ Fig. S2). Detailed analysis of the $\mathrm{Ow}-\mathrm{H}$ RDF shows that in agreement with expected more acidic properties of the $\mathrm{H}_{2} \mathrm{O}$ coordinating the Ag-ion, proton donation events take place between water in Ag-coordination shell and interstitial water (Albuquerque and Calzaferri 2007; Fois and Tabacchi 2019).

\section{Crystal structure of intergrown Ag-erionite}

The structural parameters of Ag-exchanged erionite and relevant bond distances are reported in Supplemental ${ }^{1}$ Table S3 and Table 3, respectively. The $P 6_{3} / m m c$ characteristic of the natural

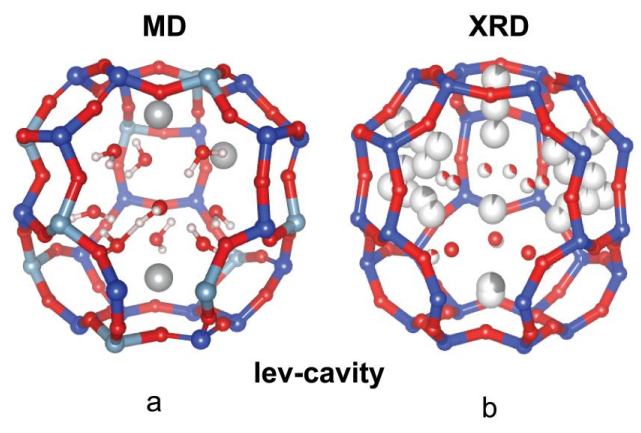

Figure 5. Silver and water molecules distribution within the lev cavity of the (a) calculated (snapshot after 18 ps calculation) and refined (b) Ag-levyne structure. (Color online.)
TABLE 3. Relevant bond distances $(\AA ̊)$ of Ag-erionite structure at room temperature

\begin{tabular}{|c|c|c|c|}
\hline \multicolumn{4}{|c|}{ Framework } \\
\hline T1-O1 & $1.651(2)$ & $\mathrm{T} 2-\mathrm{O} 3$ & $1.6231(18)$ \\
\hline T1-O2 & $1.634(2)$ & $\mathrm{T} 2-\mathrm{O} 4 \times 2$ & $1.649(4)$ \\
\hline $\mathrm{T} 1-\mathrm{O} 4$ & $1.649(4)$ & $\mathrm{T} 2-\mathrm{O} 5$ & $1.646(3)$ \\
\hline T1-O6 & $1.650(2)$ & $<\mathrm{T} 2-\mathrm{O}>$ & 1.642 \\
\hline$<\mathrm{T} 1-\mathrm{O}>$ & 1.646 & & \\
\hline \multicolumn{4}{|c|}{ Extraframework } \\
\hline $\mathrm{K} 1-01 \times 6$ & $2.941(6)$ & C $3-W 4 A \times 2$ & $2.63(2)$ \\
\hline $\mathrm{K} 1 \mathrm{~A}-\mathrm{O} 1 \times 3$ & $2.51(11)$ & & \\
\hline $\mathrm{K} 1 \mathrm{~A}-\mathrm{O} 6 \times 3$ & $3.09(17)$ & & \\
\hline $\mathrm{C} 1-\mathrm{O} 6 \times 2$ & $2.500(6)$ & & \\
\hline $\mathrm{C} 1-\mathrm{O} 4 \times 2$ & $2.986(5)$ & & \\
\hline $\mathrm{C} 2-\mathrm{O} 5 \times 3$ & $2.487(11)$ & & \\
\hline $\mathrm{C} 2 \mathrm{~A}-\mathrm{O} 5 \times 3$ & $2.410(10)$ & & \\
\hline $\mathrm{C} 2 \mathrm{~B}-\mathrm{O} 5 \times 3$ & $2.640(14)$ & & \\
\hline C2B-W5 & $2.29(6)$ & & \\
\hline
\end{tabular}

erionite (Alberti et al. 1997) is preserved after the uptake of $\mathrm{Ag}$ ions. The unit cell $[a=13.29919(19), c=15.19312(19) \AA, V=$ $\left.2327.17(7) \AA^{3}\right]$ is slightly smaller compare to that of an erionite sample from the same locality $[a=13.345(1), c=15.124(3) \AA$, $\left.V=2332.6(5) \AA^{3}\right]$ reported by Passaglia et al. (1998). According to the structural refinement, $\mathrm{K}$ occupies the middle of the cancrinite cage, where it is slightly displaced along $z$ direction as demonstrated by the occurrence of an additional site $\mathrm{K} 1 \mathrm{~A}$ $[$ occupancy $=0.030(16)$ ] at 0.8(3) $\AA$ from K1 [occupancy $=$ $0.98(4)$ ] (Fig. 6). This finding is in agreement with Sherry (1979) who reported that potassium in the cancrinite cavities cannot be replaced via ion exchange in aqueous solution because of the small opening of the six-membered ring window, which hampers the passage of the $\mathrm{K}$ ions.

Ag ions are distributed in the eri cavity, at disordered sites with partial occupancies (Fig. 6). Three main positions can be recognized:

- $\mathrm{C} 1$, the most occupied site [occupancy $=0.679(14)]$ is located in the erionite cavity close to the six-membered

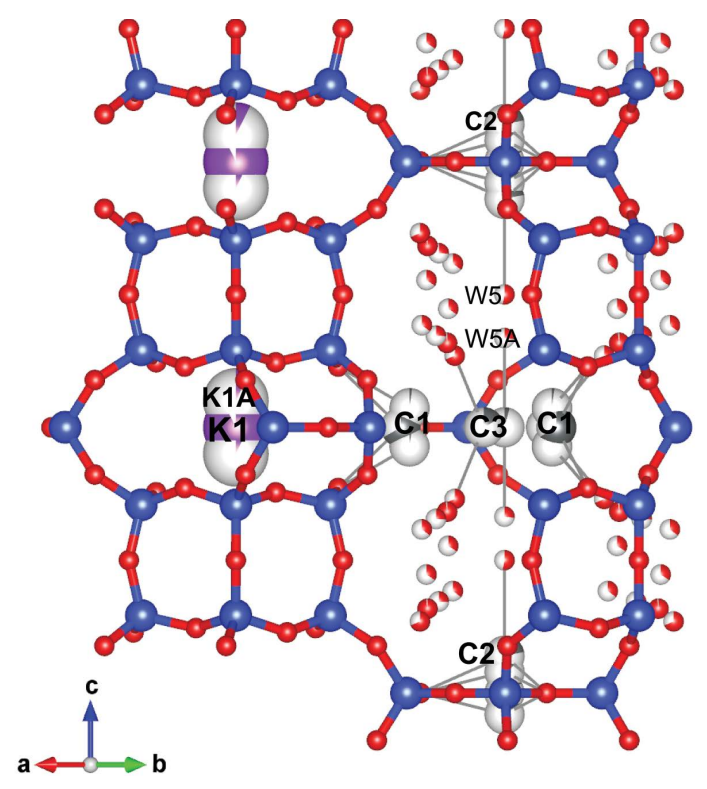

FiguRE 6. Crystal structure of Ag-erionite refined from XRD. Color code as in Figure 2. Purple spheres represent $\mathrm{K}$ atoms. Gray lines indicate $\mathrm{Ag}-\mathrm{O}$ bonds in the eri cavity. (Color online.) 
ring aperture of the cancrinite cage; it forms two bonds with framework oxygen at O6 [2.500(6) §] and two longer connections $[2.986(5) \AA]$ with those at O4. A very low occupied site $\mathrm{C} 1 \mathrm{~A}$ close to $\mathrm{C} 1$ indicates, also in this case, a displacement from the mirror plane perpendicular to [001].

- $\mathrm{C} 2$, disordered at three different subsites $(\mathrm{C} 2, \mathrm{C} 2 \mathrm{~A}$, $\mathrm{C} 2 \mathrm{~B}$, with total occupancy $=0.53$ ) distributes at the bottom and top of the erionite cavity in the aperture center of the 6-membered rings. Ag ions at this position form bonds with framework oxygen $\mathrm{O} 5$ of the six-membered ring and with $\mathrm{H}_{2} \mathrm{O}$ at W5 site, which is located along the threefold axis.

- $\mathrm{C} 3, \mathrm{C} 3 \mathrm{~A}$, and C3B (total occupancy $=0.21$ ) are located in the middle of the eri cavity and bond only to $\mathrm{H}_{2} \mathrm{O}$ at W5A and W4A.

All water molecules, but those at W5 and W5A, are distributed over five sites at the wall of the eri cavity in correspondence of the 8-membered ring window (Supplemental ${ }^{1}$ Table S3; Fig. 6).

The total number of positive charges obtained by the structural refinement $\left(11.3^{+}\right)$is in reasonable agreement with that estimated by the chemical analysis $\left(12.3^{+}\right)$.

\section{Discussion}

The analysis of the erionite intergrowths demonstrated that all EF cations in the eri cavity could be exchanged with $\mathrm{Ag}^{+}$, and, differently from Ag-levyne, all Ag ions in the unit cell could be located by the structural refinement. The lack of ca. $30 \%$ of $\mathrm{Ag}^{+}$in Ag-levyne structure can be explained by (1) migration of part of silver toward the external surface, or (2) strong disorder of the remaining $\mathrm{Ag}^{+}$in the structural voids, which prevents its exact location.

Since positional disorder of EF sites was observed also in Ag-erionite, but all Ag could be located, we decided to collect additional XRD data on Ag-levyne by using the more brilliant $\mathrm{Cu}$ micro-focused source employed to investigate Ag-erionite. The other two fragments of Ag-levyne were selected and data were collected on the same instrument used for Ag-erionite. As an example, data-collection parameters and results obtained for the first fragment are reported in Supplemental ${ }^{1}$ Tables S4 and S5. Structural refinements did not show any significant change in terms of EF cation positions, but, in both cases, the refined chemical composition indicated an Ag content higher than $5 \mathrm{apfu}$. Such a value can be reasonably accepted if the errors on refined values of both occupancies and thermal parameters are taken into account (Supplemental ${ }^{1}$ Table S5). Thus, the disorder hypothesis 2 seems the most reasonable. Such a hypothesis is also supported by similar findings in hydrated fully exchange Ag-chabazite and Ag-heulandite (Nevenka et al. 1981; Calligaris et al. 1983). In both cases, the authors could not locate by XRD methods all Ag ions revealed by the chemical analyses. In Agexchanged heulandite, only $56 \%$ of exchanged $\mathrm{Ag}^{+}$was detected by X-ray (Nevenka et al. 1981). Similarly, in Ag-chabazite only $61 \% \mathrm{Ag}^{+}$could be placed by the structural refinement (Calligaris et al. 1983). The interpretation given by the authors was that remaining Ag ions "spread out in the channels of the zeolite... giving no detectable contribution to the diffraction pattern" (Nevenka et al. 1981).
According to our findings, the distribution of $\mathrm{Ag}^{+}$in the two intergrown phases slightly differs. In erionite, the disorder that affects the Ag ions is less pronounced; with the exceptions of $\mathrm{C} 1 \mathrm{~A}, \mathrm{C} 3 \mathrm{~A}$, and $\mathrm{C} 3 \mathrm{~B}$ sites, the occupancies of all EF sites are higher than 0.15 , and most of the $\mathrm{Ag}$ is found at $\mathrm{C} 1$ site [occupancy $=0.679(14)$ ]. In Ag-levyne, apart from Ag1 [occupancy = $0.429(19)$ ], ions are distributed at sites with occupancies $<0.15$. In particular, silver ions at the wall of the lev cavity are significantly disordered and affected by high displacement parameters that strongly influence the final values of the refined occupancies.

Overall, the exchange of the original EF cations with $\mathrm{Ag}^{+}$ in the levyne structure does not induce significant structural modifications of the framework. The $\mathrm{Ag}^{+}$ions distribute at different crystallographic sites compared to levyne-Ca and to levyne-Na. In particular, the sites at Ag4-Ag4E sites are located at the aperture of the eight-membered rings of the lev cavity where natural levyne $\mathrm{H}_{2} \mathrm{O}$ molecules are found. Such distribution was confirmed by the MD simulations, which indicated a displacement of the EF cations away from the threefold axis. MD trajectories also pointed out the occurrence of a silver ion located inside the D6R cage. However, according to XRD results, no residual electron density was found at this position.

To explain this mismatch, we have to keep in mind that in real exchange experiments, not only the availability but also the accessibility of the EF sites must be considered; the latter is related to the kinetic behavior of the ion-exchange system and thus to the diffusion coefficients of that specific ion within the pores (Inglezakis et al. 2004). The diffusion and the ability of an ion to access a specific site may depend on its hydration shell. From the structural refinement, we could not unambiguously determine the exact water content, due to the strong disorder of the EF occupants. MD simulations with $3 \mathrm{H}_{2} \mathrm{O}$ per $\mathrm{Ag}$ ion, represent an idealized chemical composition of levyne- $\left(\mathrm{Ca}_{0.5}, \mathrm{Na}\right)_{6}$ (Passaglia and Sheppard 2001). However, in Ag-levyne, the number of EF cations is 1.5 greater than in levyne-Ca (1 Na plus $2.5 \mathrm{Ca}$ apfu). A possible reason for the presence of $\mathrm{Ag}^{+}$inside the D6R cage could be the overestimation of the number of structural $\mathrm{H}_{2} \mathrm{O}$; less room for $\mathrm{Ag}$ ions in the $\mathrm{lev}$ cavity would force them to enter inside the D6R cage. To test the effect of $\mathrm{H}_{2} \mathrm{O}$ amount on the Ag distribution in LEV framework type, additional Molecular Dynamics simulations (12 ps long trajectories) of Ag-levyne structure with different water content were performed. At first, we hypothesized $2.5 \mathrm{H}_{2} \mathrm{O}$ (instead of 3 ) per $\mathrm{Ag}$ ion, which is $15 \mathrm{H}_{2} \mathrm{O}$ pfu. With such configuration, only $30 \%$ of the D6R cage is occupied by an $\mathrm{Ag}$ ion. When removing an additional $0.5 \mathrm{H}_{2} \mathrm{O}$, i.e., modeling a structure with only $2 \mathrm{H}_{2} \mathrm{O}$ per $\mathrm{Ag}$ ion $\left(12 \mathrm{H}_{2} \mathrm{O}\right.$ pfu $)$, no EF cations are found inside the cage at $(0,0,0)$ (Fig. 7$)$. In both cases, displacement of part of Ag ions from the threefold axis toward the 8-membered ring window was observed.

Based on these results, the structure containing $2 \mathrm{H}_{2} \mathrm{O}$ per $\mathrm{Ag}$ ion represents the best agreement between experimental (XRD) and calculated (MD) Ag-levyne. It should be kept in mind that the amount of structural (and absorbed) water in a zeolitic material is strongly influenced by the environmental conditions the sample is exposed to (i.e., relative humidity, temperature). It is worth mentioning that in one of the data sets collected as a test (by using the $\mathrm{Cu}$ micro-focus source) on a fragment of Ag-levyne, 


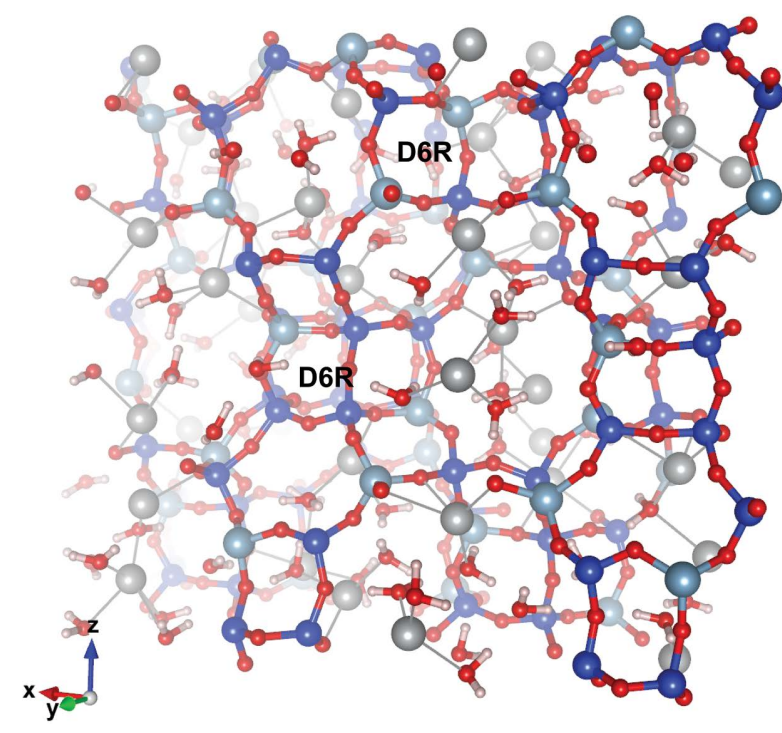

Figure 7. Perspective view of the simulated (11 ps) Ag-levyne supercell with $2 \mathrm{H}_{2} \mathrm{O}$ per Ag ions. Color code as in Figure 3. Ag ions are not found in the D6R cages. (Color online.)

a tiny peak at $(0,0,0)$ appeared in the difference Fourier maps. Nevertheless, an attempt to insert it in the structural refinement did not lead to satisfactory results; the refined value was as big as the computed error. Interestingly, the occurrence of a cation at this position, i.e., $(0,0,0)$, was found in the dehydrated form of levyne-Ca (Arletti et al. 2013; Cametti 2018).

\section{IMPLICATIONS}

Currently, natural zeolites are effectively applied for wastewater treatment and removal of contaminants. On the other hand, their use in other important fields such as catalysis or gas separation processes is still limited. In the last decades, much effort has been made to improve the catalytic and separation potential. The functionalization and modification of the natural zeolites by thermal treatment or ion-exchange has been one of the most used and successful technique (Zukal et al. 2010; Ma et al. 2018; Abreu et al. 2019; Velazquez-Peña et al. 2019). The specific case of Ag-modified zeolites is particularly interesting because silver is known to strongly influence the adsorption characteristics of aluminosilicate zeolites (Hutson et al. 2000). For example, modified Ag-ferrierite and Ag-mordenite are applied in air purification processes $\left(\mathrm{Ar} / \mathrm{O}_{2}\right.$ enrichment or exhaust gas cleanup) (Knaebel and Kandybin 1993; Ogawa et al. 2001). In addition, Ag-exchanged zeolites have attracted great attention due to their remarkable luminescent and photocatalytic properties (De Cremer et al. 2009; Countino-Gonzales et al. 2015; Aghakhani et al. 2018). In this context, particular attention must be paid not only to the framework topology and to the size of the micropores but also, and especially, to the cation positions in the structural voids (Seifert et al. 2000; Aghakhani et al. 2018; Fron et al. 2019). Previous research on transition-metal modified zeolites have shown that even if the structure experiences little modifications of the framework at room temperature, the new extraframework cations have a significant influence on the dehydration path (i.e., phase transformations) and thermal stability of the newly produced zeolite. With this respect, a hightemperature structural study is in progress to check whether Aglevyne will undergo, upon heating, different structural changes compare to levyne-Ca.

\section{ACKNOWLEDGMENTS}

We are thankful to B. Hoffman of Natural History Museum of Bern who provided the levyne sample, M. Nagashima for her help with EMPA analyses, and to T. Armbruster for reading the manuscript. Gloria Tabacchi and an anonymous reviewer are thanked for their very constructive comments.

\section{FUNDING}

We acknowledge access to the Swiss National Supercomputing Center (CSCS) and UBELIX HPC cluster at the University of Bern. The Swiss National Science Foundation (SNF) is acknowledged for the Ambizione grant no. PZ00P2 173997 awarded to G.C. and for the R'Equip grant n. 206021_177033 awarded to P. Macchi.

\section{REFERENCES CITED}

Abreu, N.J., Valdés, H., Zaror, A.C., Azzolina-Jury, F., and Meléndrez, M.F. (2019) Ethylene adsorption onto natural and transition metal modified Chilean zeolite: An operando DRIFTS approach. Microporous and Mesoporous Materials, $274,134-148$.

Ackley, M.W., Rege, S.U., and Saxena, H. (2003) Application of natural zeolites in the purification and separation of gases. Microporous and Mesoporous Materials, 61, 25-42.

Aghakhani, S., Grandjean, D., Baekelant, W., Coutiño-Gonzales, E., Fron, E., Kvashnina, K., Roeffaers, M.B.J., Hofkens, J., Sels, B.F., and Lievens, P. (2018) Atomic scale reversible opto-structural switching of few atom luminescent silver clusters confined in LTA zeolites. Nanoscale, 10, 11467-11476.

Alberti, A., Martucci, A., Galli, E., and Vezzalini, G. (1997) A re-examination of the crystal structure of erionite. Zeolites, 19, 349-352.

Albuquerque, R.Q., and Calzaferri, G. (2007) Proton activity inside the channels of zeolite L. Chemistry, a European Journal, 13, 8939-8952.

Amooghin, A.B., Omidkhah, M., Sanaeepur, H., and Kargari, A. (2016) Preparation and characterization of $\mathrm{Ag}^{+}$ionexchanged zeolite-Matrimid ${ }^{\circledR} 5218 \mathrm{mixed}$ matrix membrane for $\mathrm{CO}_{2} / \mathrm{CH}_{4}$ separation. Journal of Energy Chemistry, 25, $450-462$.

Arletti, R., Vezzalini, G., Quartieri, S., Cámara, F., and Alvaro, M. (2013) A new framework topology in the dehydrated form of zeolite levyne. American Mineralogist, 98, 2063-2074.

Babel, S., and Kurniawan, T.A. (2003) Low-cost adsorbents for heavy metals uptake from contaminated water: A review. Journal of Hazardous Material, 97, 219-243.

Bennett, J.M., and Grose, R.W. (1978) Characterization of the offretite-levynite intergrowth from Beech Creek, Oregon, by adsorption and electron diffraction. In L.B. Sand and F.A. Mumpton, Eds., Natural Zeolites. Pergamon, Oxford, pp 77-84.

Bish, D.L., and Ming, D.W. (2001) Natural zeolites: Occurrences, properties and applications. Reviews in Mineralogy and Geochemistry, 45. Mineralogical Society of America and Geochemical Society, Chantilly, Virginia.

Borai, E.H., Harjula, R., Malinen, R., and Paajanen, A. (2009) Efficient removal of cesium from low-level radioactive liquid waste using natural and impregnated zeolites minerals. Journal of Hazardous Material, 172, 416-422.

Bruker (2019) APEX3, v2019.1-0. Bruker AXS Inc., Madison.

Calligaris, M., Nardin, G., and Randaccio, L. (1983) Cation site location in hydrated chabazites. Crystal structure of potassium- and silver-exchanged chabazites. Zeolites, 3, 205-208.

Cametti, G. (2018) New topology of levyne B under quasi-equilibrium conditions: A temperature-dependent in situ single crystal X-ray diffraction study. Microporous and Mesoporous Materials, 265, 162-171.

Cametti, G., Scheinost, A.C., Giordani, M., and Churakov, S.V. (2019a) Framework modifications and dehydration path of $\mathrm{Ag}^{+}$-modified zeolite with STI framework type. Journal of Physical Chemistry C, 123, 13651-13663.

Cametti, G., Scheinost, A.C., and Churakov, S.V. (2019b) Structural modifications and thermal stability of $\mathrm{Cd}^{2+}$-exchanged stellerite, a zeolite with STI framework type. Journal of Physical Chemistry C, 123, 25236-25245.

Colella, C. (1999) Environmental applications of natural zeolitic materials based on their ion-exchange properties. In P. Misaelides, F. Macasek, T.J. Pinnavaia, and C. Colella, Eds., Application of natural microporous materials in environmental technology, Kluwer, NATO Science Series vol. E362 (Applied Sciences), Dordrecht.

Coutino-Gonzales, E., Baekelant, W., Grandjean, D., Roeffaers, M.B.J., Fron, E., Aghakhani, M.S., Bovet, N., Van der Auweraer, M., Lievens, P., Vosch, T., and others. (2015) Thermally activated LTA(Li)-Ag zeolites with waterresponsive photoluminescence properties. Journal of Material Chemistry C, 
$3,11857-11867$.

CP2K (2000-2019) CP2K software. CP2K Foundation. http://www.cp2k.org

CrysAlis Pro (2018) CrysAlis Pro software, Version 171.40.29a. Rigaku. https:// www.rigaku.com/products/smc/crysalis

De Cremer, G., Coutino-Gonzales, E., Roeffaers, M.B.J., Moens, B., Ollevier, J., Van der Auweraer, M., Schoonheydt, R., Jacobs, P.A., De Schryver, F.C., Hofkens, J., and others. (2009) Characterization of fluorescence in heattreated silver-exchanged zeolites. Journal of American Chemical Society, 131, 3049-3056.

Ferreira, L., Fonseca, A.M., Botelho, G., Aguiar, C.A., and Neces, I.C. (2012) Antimicrobial activity of faujasite zeolites doped with silver. Microporous and Mesoporous Materials, 160, 126-132.

Flanigen, E.M., Lok, B.M., Patton, R.L., and Wilson, S.T. (1986) Aluminophosphate molecular sieves and the periodic table. Pure and Applied Chemistry, 58, 1351-1358.

Fois, E., and Tabacchi, G. (2019) Water in zeolite L and its MOF mimic. Zeitschrift für Kristallographie-Crystalline Materials, 234, 2018-2153.

Fron, E., Aghakhani, S., Baekelant, W., Grandjean, D., Coutino-Gonzales, E., Van der Auweraer, M., Roeffaers, M.B.J., Lievens, P., and Hofkens, J. (2019) Structural and photophysical characterization of Ag clusters in LTA zeolites. Journal of Physical Chemistry C, 123, 10630-10638.

Gatta, G.D., Lotti, P., and Tabacchi, G. (2018) The effect of pressure on openframework silicates: elastic behaviour and crystal-fluid interaction. Physics and Chemistry of Minerals, 45, 115-138.

Gottardi, G., and Galli, E. (1985) Natural Zeolites. Springer-Verlag.

Grimme, S. (2006) Semiempirical GGA-type density functional constructed with a long-range dispersion correction. Journal of Computational Chemistry, 27, 1787-1798.

Hutson, N.D., Reisner, B.A., Yang, R.T., and Toby, B.H. (2000) Silver ionexchanged zeolites Y, X, and low-silica X: Observations of thermally induced cation/cluster migration and the resulting effects on the equilibrium adsorption of Nitrogen. Chemistry of Materials, 12, 3020-3031.

Inglezakis, V.J., Loizidou, M.M., and Grigoropoulou, H.P. (2004) Ion exchange studies on natural and modified zeolites and the concept of exchange site accessibility. Journal of Colloid and Interface Science, 275, 570-576.

Kasture, M.W., Joshi, P.N., Sorti, H.S., Joshi, V.V., Choudhari, A.L., and Shiralkar, V.P. (1998) Sorption properties of the natural, $\mathrm{K}$ and partially deammoniated $\left(\mathrm{H} / \mathrm{NH}_{4}\right)$ forms of clinoptilolite. Adsorption Science and Technology, 16, 135-151.

Kanazawa, T. (2004) Development of hydrocarbon adsorbents, oxygen storage materials for three-way catalysts and $\mathrm{NO}_{x}$ storage-reduction catalyst. Catalysis Today, 96, 171-177.

Knaebel, K.S., and Kandybin, A. (1993) Pressure swing adsorption system to purify oxygen. U.S. Patent US5226933A, Ohio State University.

Liang, J., Zhang, R., Zhao, Q., Dong, J., Wang, B., and Li, J. (2012) Molecular simulation of hydrogen storage in ion-exchanged mazzite and levyne zeolites. Computational and Theoretical Chemistry, 980, 1-6.

Loewenstein, W. (1954) The distribution of aluminum in the tetrahedra of silicates and aluminates. American Mineralogist, 39, Nr. 1/2, S. 92.

Lock, B.M., Messina, C.A., Patton, R.L., Gjek, R.T., Cannan, T.R., and Flanigen, E.M. (1984) Crystalline silicoaluminophosphates. U.S. Patent US4440871A, Katalistiks International Inc. Honeywell UOP LLC.

Ma, Z., Zhang, Q., Weng, X., Mang, C., Si, L., Guan, Z., and Cheng, L. (2018) Fluoride ion adsorption from wastewater using magnesium(II), aluminum(III) and titanium(IV) modified natural zeolite: Kinetics, thermodynamics, and mechanistic aspects of adsorption. Journal Water Reuse and Desalination, $8,479-489$.

Merlino, S., Galli, E., and Alberti, A. (1975) The crystal structure of levyne. Tschermaks Mineralogische und Petrographische Mitteilungen, 22, 117-129.

Milenkovic, J., Hrenovic, J., Matijasevic, D., Niksic, M., and Rajic, N. (2017) Bactericidal activity of $\mathrm{Cu}-, \mathrm{Zn}-, \mathrm{Ag}$-containing zeolites toward Escherichia coli isoltates. Environmental Science and Pollution Research, 24, 20273-20281.

Misaelides, P. (2011) Application of natural zeolites in environmental remediation: A short review. Microporous and Mesoporous Material, 144, 15-18.

Momma, K., and Izumi, F. (2011) VESTA 3 for three-dimensional visualization of crystal, volumetric and morphology data. Journal of Applied Crystallography, 44, 1272-1276.

Nevenka, B.P., Calligaris, M., Nardin, G., and Randaccio, L. (1981) Location of cations in metal ion-exchanged Zeolites. Part 2. Crystal structures of a fully silver-exchanged heulandite. Journal of the Chemical Society, Dalton
Transactions, 12, 2288-2291.

Ogawa, H., Ito, Y., Nakano, M., and Itabashi, K. (2001) Method for adsorbing and removing ethylene and method for purifying an exhaust gas. U.S. Patent US6309616B1, Tosoh Corp.

Passaglia, E., and Sheppard, R.A. (2001) The crystal chemistry of zeolites. In D.L. Bish and D.W. Ming, Eds., Natural Zeolites: Occurrence, properties, applications, 45, p. 70-116. Reviews in Mineralogy and Geochemistry, Mineralogical Society of America, Chantilly, Virginia.

Passaglia, E., Galli, E., and Rinaldi, R. (1974) Levynes and erionites from Sardinia. Contributions to Mineralogy and Petrology, 43, 253-259.

Passaglia, E., Artioli, G., and Gualtieri, A. (1998) Crystal chemistry of the zeolites erionite and offretite. American Mineralogist, 83, 577-589.

Perdew, J.P., Burke, K., and Ernzerhof, M. (1996) Generalized gradient approximation made simple. Physical Review Letters, 77, 3865-3868.

Sacerdoti, M. (1996) New refinements of the crystal structure of levyne using twinned crystals. Neues Jahrbuch für Mineraolige Monatshefte, 3, 114-124.

Seifert, R., Rytz, R., and Calzaferri, G. (2000) Colors of Ag ${ }^{+}$-exchanged zeolite A. Journal of Physical Chemistry A, 104, 7473-7483.

Sheldrick, G.M. (2008) A short history of SHELX. Acta Crystallographica, A64, $112-122$.

(2015) Crystal structure refinement with SHELXL. Acta Crystallographica, C71, 3-8.

Sherry, H.S. (1979) Ion-exchange properties of the natural zeolite erionite. Clays and Clay Minerals, 27, 231-237.

Shimazu, M., and Mizota, T. (1972) Levyne and erionite from Chojabaru, Iki island, Nagasaki Pref., Japan. The Journal of Japanese Association of Mineralogists, Petrologists and Economic Geologists, 67, 418-424.

VandeVondele, J., and Hutter, J. (2007) Gaussian basis sets for accurate calculations on molecular systems in gas and condensed phases. Journal of Chemical Physics, 127, 114105.

VandeVondele, J., Krack, M., Mohamed, F., Parrinello, M., Chassaing, T., and Hutter, J. (2005a) Quickstep: Fast and accurate density functional calculations using a mixed Gaussian and plane waves approach. Computer Physics Communications, 167, 103-128.

VandeVondele, J., Mohamed, F., Krack, M., Hutter, J., Sprik, M., and Parrinello, M. (2005b) The influence of temperature and density functional models in ab initio Molecular Dynamics simulation of liquid water. Journal of Chemical Physics, 122, 014515.

Velazquez-Peña, G.C., Solache-Ríos, M., Olguin, M.T., and Fall, C. (2019) As(V) sorption by different natural zeolite frameworks modified with $\mathrm{Fe}, \mathrm{Zr}$ and $\mathrm{FeZr}$. Microporous and Mesoporous Materials, 273, 133-141.

Wang, S., and Peng, Y. (2010) Natural zeolites as effective adsorbents in water and wastewater treatment. Chemical Engineering Journal, 156, 11-24.

Wise, S.W., and Tschernich, R.W. (1976) The chemical composition and origin of the zeolites offretite, erionite and levyne. American Mineralogist, 61, 853-863.

Yamamoto, K., Ikeda, T., Onodera, M., Muramatsu, A., Mizukami, F., Wang, Y., and Gies, H. (2010) Synthesis and structure analysis of RUB-50, an LEV-type aluminosilicate zeolite. Microporous and Mesoporous Materials, 128, 150-157.

Zhu, G.S., Xiao, F.S., Qiu, S.L., Hun, P.C., Xu, R.R., Ma, S.J., and Terasaki, O. (1997) Synthesis and characterization of a new microporous aluminophosphate with levyne structure in presence of HF. Microporous and Mesoporous Materials, 11, 269-273.

Zukal, A., Pulido, A., Gil, B., Nacthtigall, P., Bludský, O., Rubeš, M., and Čejka, J. (2010) Experimental and theoretical determination of adsorption heats of $\mathrm{CO}_{2}$ over alkali metal exchanged ferrierites with different $\mathrm{Si} / \mathrm{Al}$ ratio. Physical Chemistry Chemical Physics, 12, 6413-6422.

MANUSCRIPT RECEIVED MARCH 2, 2020

MANUSCRIPT ACCEPTED MAY 1, 2020

ManusCript handled by G. Diego Gatta

\section{Endnote:}

${ }^{1}$ Deposit item AM-20-117500, CIF and Supplemental Material. Deposit items are free to all readers and found on the MSA website, via the specific issue's Table of Contents (go to http://www.minsocam.org/MSA/AmMin/TOC/2020/ Nov2020_data/Nov2020_data.html). 